Historic, Archive Document

Do not assume content reflects current scientific knowledge, policies, or practices. 



\section{LATHAM - The Big Red Raspberry}

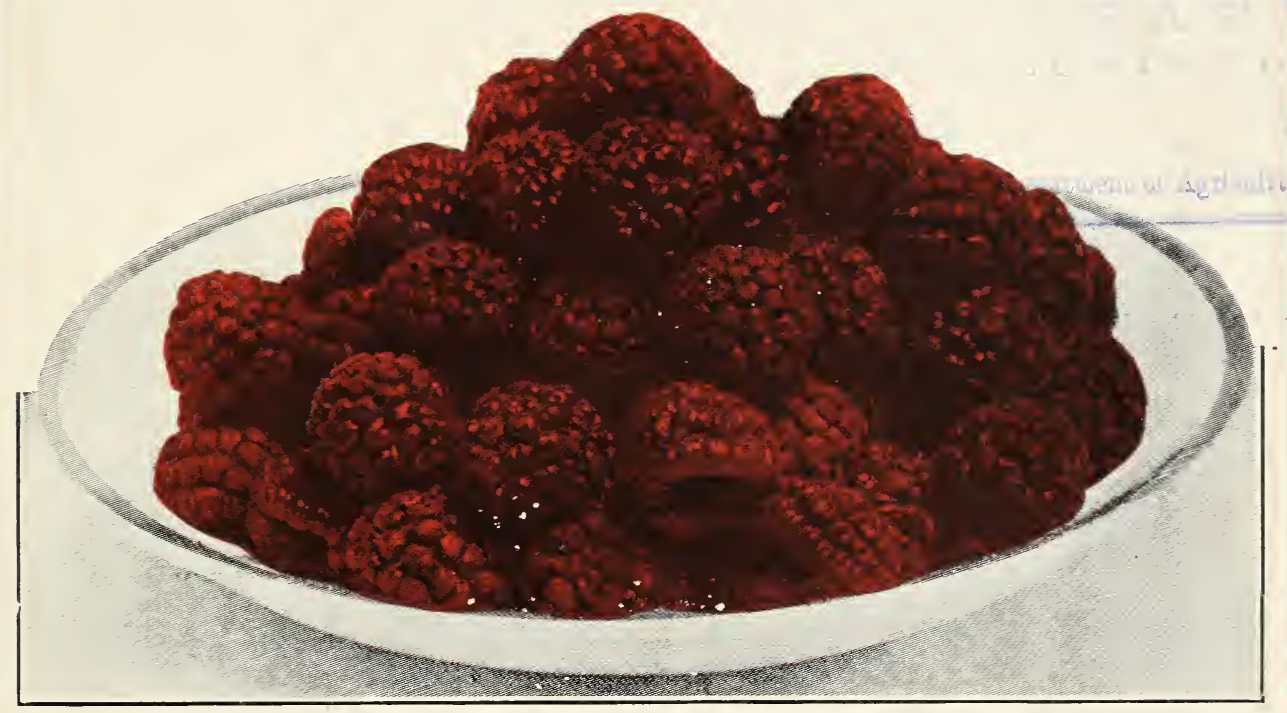

\section{Sensational in Yield and Profit!}

CROWERS are just beginning to realize that nothing will make them so $\mathcal{G}$ much money, so surely and quickly as the LATHAM RASPBERRY. There are records of fields that have produced over $\$ 1000.00$ per acre each year.

\section{A Big Money Maker for Berry Growers}

This ability of Latham to produce so heavily, together with the fine appearance of the fruit and its splendid shipping qualities make it one of the most profitable Red Raspberries now grown.

Its extreme hardiness and splendid vigor insure big crops. It stands shipping well and tops the market. It combines all of the good qualities for profitable berry raising.

\section{A Source of Pleasure and} Economy for Home Owners

Why pay 20c a pint for Raspberries at the stores when fresher berries can be so easily raised in your garden? Enjoy the pleasure and profit of growing your own.

Latham doesn't require expert attention. Our Mosaic-free plants are healthy and vigorous and produce abundantly.

Latham commence to bear soon, and continue for many years. Latham will produce the most berries for the least work of any we have ever known.

\section{Milton NuRSERY Co.}

Milton, Oregon 



\section{What Others Say About LATHAM RED RASPBERRIES}

Just a Few of the Many Letters from Satisfied Customers

Well Satisfied

Mr. Marsy 1., Jordinn, Mneleliil, Minnesotin, wrices:

"Oitr Latham bushes will make better chan 1 glirt ner bush this year ind ins this is the first yenr ind a very dry year we are well satistied. We irre getting 50e per $10 \mathrm{c}$ to $15 \mathrm{c}$ per quart above other varieties beeause they are so showy."

$\$ 1000.00$ an acre From Mosaic-Free Latham Mr. E. O. Schoembs, Frnitville Nursery, Villa Ridge, Illinois, says:-

"Ny' one year patch of Latluams planted in checks six. by six prodnced seventy-tw'o, lwenty. four pillt crates per seasoll was $\$ 6,00$.

"The fact that these plants were tlisease. free when I reeived them innd liave passed domble state inspection for two y'enrs, leaves no doubt in my mind that it will pay

"Be assured of my highest regard for the Latham

Plants That Grow

Prof. Yeomans, State Bonrl of Entomology, Atlanta, 列 "Nice plints, believe they" will slo well here."

W. T. Tapley, State College, Pemsylvaniz, writes:'l'l 725 Latham Raspleers' plauts have eome throush in fine sliape. Lost not more thin 5 plants."

Prof, G. M. Bentley, State Entomologist and Plint Pathologist, University of Temessee, says:"Phe Lathim Ras Ro

Latham Raspberries are Hardy Sir, F. Puglu, of Winnipeg, writes:-

"A patcl of twelve acres of Lallam Raspbersics, plant ed on the Brokenhead River, near Lyriitt, are standing ni (ery billug, 'They make very strong growth and are good erop.

Favorites on the Market!

Manager O. C. Skow, of Frotit Cirnwers Assneiation of Excelsior, Mimmesolil, :ay's:-

'The latham Red Raspluerry has fractirally' replared all other vitrietices in this locality."

I., P. Stancy \& Sons, l.ending Commission l"in of slimenpolis, reports:-

"Omr experience with Lahham Raspherries has been "ery satisfictory. We find they cirry' well ind nsuilly "ommand the top of the market.

\section{Quarts Per Acre!}

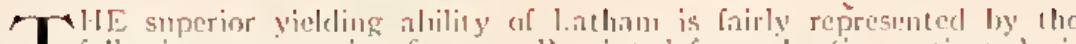

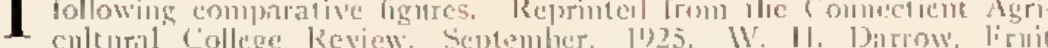

Report on 3-Year-Old Field

LATHAM, 5430 qts. per Acre. lerlert, 3648 qts. ner Aere. Culluert,

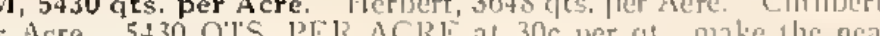
retnrII of $\$ 1629.00$ PER ACRE.

Heavy Yield at Minnesota Fruit Breeding Farm antham planted in the fall of 1924 yielded 20 crittes per nere the next D. C. Webser ater planting.

D. Webster, imit Grover at LinCreseent, Mimn, reported: - Trom $4 / 5$ of an aere sold $\$ 850.00$ worth of fruit. - irom 31/2 acres sold over $\$ 3000.00$ worth of frnic - from 3 neres sold $\$ 3200.00$ worth of fruit.
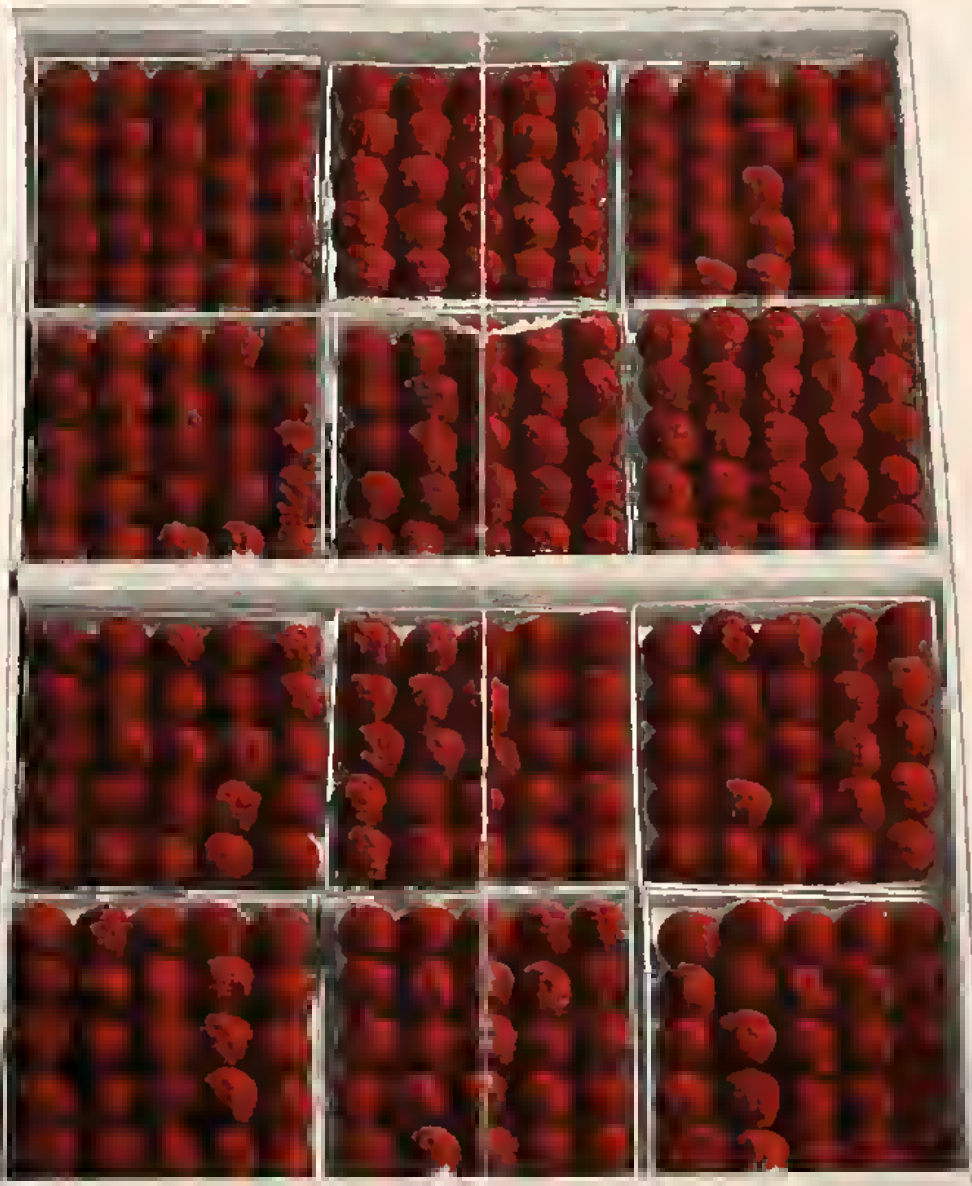

CRATE OF LATHAM RED RASPBERRY Nole tle Larbe Size of Berries.
Latham Raspberry Endorsed by Highest Authorities

From the University of Minnesota

Prof. W. H. Alderman, Chicl, Division of Ilorti. mlture, University' of Minnesotia:-

"The viriety not only" is resistant to our winter eonch. tions, but it is also one of the most proluctive raspberries with which we are familiar.

"Its attraetive eoloring and firmness give it sueh favor. hlale appearanee on the market that it ordinitrily' commands a prenium of fifty cents a case over anel alrovi the price of the ordinary' raspberry.

"When grown on slock free from Mosaic disense, this rasplyerry ean hardly' be excelled by any which may be grow'n in this or adjoining stattes."

From North Dakota Experiment Station Prof, A. F, Yeager, Norll, Diketa Experimen! Siltion:-

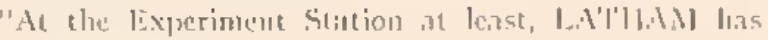
onvichled any of les viariety two 10 one. No protectinn is necessary here."

From the Gardeners Chronicle Harold N. Bryng, in CARDENERS CHRONICLL:"The Lithinm is withont loubt the best rinl masploerry "The Lat the grower to plant loday. It las proven entircly harely in the Datiolas and the Northwest. It is i splendial cropper, bearing fruit the largest ancl fromest I linve secen on any sariety and holding the size thronghont it lont

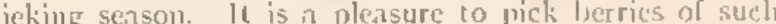
size and of delectible anpearance."

Has Many Points of Merit LATII:H is the mane given to the masphersy ilant wa origimally known as Mimm. No. J. I has illow Ikent

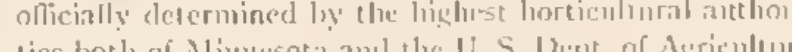

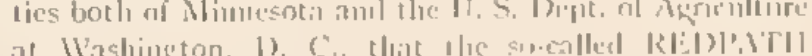

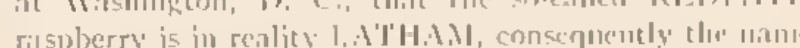
Redpath is now clropined from the lists. I.dilldal has more points of incrit and has coure into general plinginu

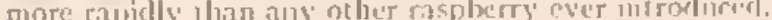




\section{Why Our LATHAM Red Raspberry Plants Are Superior To Others:}

\section{BETTER FRUIT AND MORE OF IT FROM OUR LATHAM BECAUSE THEY ARE}

"MOSAIC-FREE." Read what these authorities say of "Mosaic-free" Latham.

PROF. A. G. RUGGLES, Chief, Minnesota Nursery Inspection Service, says, "The superiority of disease free stock cannot be questioned."

The cause for the "running out" of raspberries has been due chiefly to what is known as "Mosaic disease." Mosaic gradually weakens ordinary plants until they become unprofitable. However, when Mosaic-free plants are secured they will remain disease-free if not planted close to infected plants. Our Latham are "Mosaic-free."

GEO. M. DARROW, Bureau of Plant Pathology, Washington, D. C., writes regarding certified "Mosaic-free" raspberry stock:

"Growers are insured clean stock for future planting that will give more profitable fields for a longer period of years than they previously obtained.'

\section{FRUIT FROM MOSAIC-FREE PLANTS BRING MORE MONEY}

One canning company in Wisconsin pays $\$ 1.00$ per crate more for berries from Mosaic-free Latham than for fruit from common diseased fields. This canning company found that fruit from healthy Latham plants makes a superior canned product. It has better color, better flavor and does not crumble as do the others.

The superior canning qualities of fruits from these plants appeal alike to commercial canners and to the house wife.

\section{EASY TO GROW}

Latham Raspberries can be easily grown in the home fruit garden and they require little care.

Set red raspberry plants $3^{\prime}$ to $5^{\prime}$ apart in rows $6^{\prime}$ to $8^{\prime}$ apart. Plant 2 or 3 inches deeper than they were in the nursery. Cut back all stems as soon as planted to within 1 to 3 inches of the ground. Don't let any fruit set first year. Cultivate well between the rows to destroy weeds and sprouts, not allowing the new shoots to make rows over 6 to 8 inches wide. After fruiting cut out old canes and burn, leaving 6 or 8 vigorous new ones to grow for fruiting the following year. In the spring cut off the top 12 inches or possibly more of previous season's growth to strong, well ripened wood.

\section{RELIABLE PLANTS INSURED}

We have spared no effort to produce No. 1 stock in every respect. Our plants have a national reputation. By constant watching and spraying we maintain our fields in perfect health. They are inspected several times each season by the State Nursery Inspector and have been pronounced to be in EXCELLENT CONDITION.

Our Stock is the REDPATH STRAIN OF LATHAM considered by many to be superior to the Common Latham in point of yield, firmness of fruit, and hardiness.

\section{Start right! Plant LATHAM (Redpath Strain) Mosaic-free Stock}

\section{MilTON NuRSERY Co. \\ Milton, Oregon}

